\title{
Bioeconomy: The Challenge in the Management of Natural Resources in the 21st Century
}

\author{
Alexandra Leitão \\ Católica Porto Business School, Universidade Católica Portuguesa, Porto, Portugal \\ Email: apleitao@porto.ucp.pt
}

How to cite this paper: Leitão, A. (2016) Bioeconomy: The Challenge in the Management of Natural Resources in the 21st Century. Open Journal of Social Sciences, 4 , 26-42.

http://dx.doi.org/10.4236/jss.2016.411002

Received: August 9, 2016

Accepted: November 22, 2016

Published: November 29, 2016

\begin{abstract}
Countries and regions around the world face a number of economic, environmental and social challenges. Increased demand for energy, primary resources (agricultural, forestry and fishing), industrial products and services (healthcare in particular) put significant pressure on the sustainability of the ecosystems that support our society. One option to provide a more sustainable base for the economy would be the transition towards bioeconomy in which the importance of biotechnology and biomassbased production to generate economic output is significantly greater than today. Bioeconomy is considered to encompass all economic activity connected with the utilization of renewable biological resources. The aim of this paper is to draw attention to the importance of bioeconomy in the management of natural resources in the 21st century, providing many answers to resolve the previous challenges together with environmental preservation. The concept has gained scientific and political attention during the recent years, especially in Europe but also globally. From the review and analysis of the literature, this paper addresses the emerging bioeconomy, definitions and conceptual bases, and its great potential in different sectors of economic activity and development of new products. Special emphasis is placed on the case of the European Union. We present the concerns of European authorities at this level and best practices already in force in two Nordic countries that can be regarded as the beginning of a general transition to bioeconomy.
\end{abstract}

\section{Keywords}

Bioeconomy, Sustainability, Innovation, Depletion of Resources, Management of Renewable Resources

\section{Introduction}

The world is now experiencing the consequences of the overexploitation of natural resources by man and of technological development. The growing concern about the 
continued loss of biodiversity and ecosystem services associated with the extinction of many species of living beings and with the lack of quality water (Murray et al., 2012) [1], the cost of food and energy security, among others, have major economic implications and significant repercussions on the well-being of populations. Environmental issues are inseparable from social issues.

Global economy has reached such a dimension that society must bear in mind that it does not operate within an unlimited ecosystem and that the increase in the flow of materials and energy in consumption clashes with the planet's physical limitations and with the life-support elements provided by natural ecosystems (Daly, 2005) [2]. In a broader economic and ecological view, natural capital depletion must be seen as a doubly evil process for society: the loss of tangible material flows (natural resources) and the potentially irreversible loss of elements that generate intangible benefit flows (ecosystem services) ${ }^{1}$.

Moreover, the global demand for water and energy is estimated to grow between 30\% and $40 \%$ in the next twenty years (IEA, 2013) [4]. Along the same lines, total demand for food, animal feed and fibres is expected to grow about $60 \%$ between today and 2050 , whereas the area of arable farmland per capita may decrease at $1.5 \%$ a year if great measures regarding policy change are not taken (FAO, 2012) [5]. The problem is now becoming so serious that in the period from 2005 to 2009, foreign land purchase in developing countries worldwide has totalled an area close to the size of Spain. In some countries, particularly in Asia, a large share of agricultural areas was and is still being sold to foreign investors from many different parts of the world (Rulli et al., 2013) [6].

Other global pressures on the environment have risen at an unprecedented pace since the 1990s, mainly driven by: (i) an increasingly multipolar world, i.e., after a relatively small number of countries dominated global production and consumption, a rebalancing of the economic power is currently under way, especially in Asian countries, with impacts on the interdependencies and on global trade and a consequent intensification of global competition for resources, biological and mineral, and fossil fuels; (ii) the changes in prevailing diseases, since the growth of the world population and its increasing mobility, especially to urban centres, increases the risk of exposure to new pandemics, usually associated with precarious food distribution (IPPC, 2013) [7], ${ }^{2}$ and (iii) the increasing environmental pollution directly linked to climate change, which exposes ecosystems to levels of pollution with ever more complex mixtures, aggravating the negative impact on human societies (e.g., food security and extreme weather phenomena).

The above-mentioned trends and the economic growth based on current consumption and production patterns, technological change as well as demographic growth ${ }^{3}$, call

\footnotetext{
${ }^{1}$ Sixty percent of the ecosystem services have deteriorated in the last fifty years (UN, 2010) [3].

${ }^{2}$ Approximately $54 \%$ of the world population lives in urban centres, a proportion expected to increase to $66 \%$ in 2050 (DESA/UN, 2014) [10].

${ }^{3}$ Projections for 2050 point to a population of approximately 9 billion people (UN, 2013) [11]. Moreover, today, less than 2 out of a global population of 7 billion (October, 2011) are considered middle-class consumers. In 2050, this number will rise to over 5 billion, coming mainly from emerging countries (Kharas, 2010) [12].
} 
the planet's ecological limits into question and stress the importance of the link between economic and environmental sustainability.

The current economic models and their needs in terms of natural resources do not guarantee the continued use of the environment to meet material needs and, at the same time, provide the benefits of a healthy life. The cost, human or social, of the collateral damage of economic activity, such as air and water pollution, polluted food and the consequent negative effects for human and animal health, is not included in the GDP.

The significant improvements that have taken place in resource efficiency are in themselves insufficient. Profound changes in institutions, practices, technology, lifestyles and dominant ways of thinking are required, namely fighting for the total decoupling of economic growth and environmental degradation in order to obtain resilient and stable ecosystems.

One option to provide a more sustainable base for the economy, which has grown in importance at global level over recent years in response to the growing concern of peoples and policy-makers, would be the transition towards bioeconomy in which the importance of biotechnology and biomass-based production to generate economic output is significantly greater than today (OECD, 2009) [8].

Bioeconomy is based on the innovative use of sustainable biological resources to cover the growing demand of the food, energy and industrial sectors together with environmental preservation. As the world population continues to grow against a background of finite natural resources, renewable biological resources are needed to secure healthy food and animal feedstuffs and for materials and other bio-based products such as biofuels.

Hence, bioeconomy can be seen as a promising sector with remarkable future potential and many business opportunities, capable of generating added value for biomass through its conversion and production (Luoma et al., 2011) [9], whilst addressing the integrated challenges of sustainability-economic, social, and environmental.

To make the transition towards bioecomy not only possible but also sustainable, new technologies and an efficient use of biomass resources will be necessary.

The emergence of the bioeconomy agenda has been underway for three decades. One could argue that it began with the Brundtland Commission in the 1980s. With it sustainability became a cornerstone of economic development. In the1990s, biotechnology emerged as a priority sector for growth and development. In the 2000s, clean tech was added to many national and regional development agendas.

Merging these development approaches-and adding the recent economic and financial crisis that led to renewed policy interest for the development of primary industries (agriculture, fishery and forestry) - is the backbone of today's bioeconomy agenda (Teräs et al., 2014) [13]. The topic has gained scientific and political attention worldwide in recent years, especially in Europe (see e.g., Kleinschmit et al., 2014) [14].

The aim of this paper is to draw attention to the importance of bioeconomy in the management of natural resources in the $21^{\text {st }}$ century and as a way of addressing the 
major challenges that the world is facing: (i) increasing populations that must be fed; (ii) depletion of natural resources; (iii) impacts of ever increasing environmental pressures and (iv) climate change.

Special emphasis is placed on the case of the European Union. We present the concerns of European authorities at this level and a few examples of best practice already in force that can be regarded as the beginning of the general transition to bioeconomy.

The methodology behind the paper is based on a review of recent literature, including peer-reviewed material and other studies by international bodies and government institutions. Given the growing literature on the topic, this review does not intend to be thorough and focuses more particularly on Europe.

Next section clarifies the concept of bioeconomy and section 3 other related relevant concepts. Section 4 focuses on the challenges faced by the emerging bioeconomy. Section 5 provides an overview of bioeconomy in Europe and section 6 focuses the Nordic countries in particular. Finally, the last section concludes.

\section{The Concept of Bioeconomy}

The term "bioeconomy" may be used with several meanings:

- A sustainable, eco-efficient transformation of the waste of renewable bio-resources in food, energy and products for other industries (DG Research, 2006) [15].

- The production and conversion of sustainable biomass, including organic waste, in the broad sense, into a variety of food, health, fibres and industrial products and energy (EPSO, 2011) [16].

- The European Commission defines the bioeconomy as, "the production of renewable biological resources and the conversion of these resources and waste streams into value added products, such as food, feed, bio-based products and bioenergy" (European Commission, 2012, p. 3) [17]. The concept of bioeconomy covers all sectors of the economy-agriculture, forestry, fisheries, food, biotechnology and the chemical industry - that process biological resources from different ecosystems.

- For the OECD, bioeconomy can be thought of as a world where biotechnology contributes to a significant share of economic output. The emerging bioeconomy is likely to involve three elements: (i) the use of advanced knowledge of genes and complex cell processes to develop new processes and products, (ii) the use of renewable biomass ${ }^{4}$ and efficient bioprocesses to support sustainable production, and (iii) the integration of biotechnology knowledge and applications across sectors ${ }^{5}$.

Bioeconomy is thus presented as a new paradigm that operates and manages the value hidden in bio-resources and bio-processes in a sustainable manner for the 21st

${ }^{4}$ Biomass can be of forestry, agricultural or aquatic origin, either virgin or as residue. It is defined as the material of biological origin excluding material embedded in geological formations and/or fossilized (CEN, 2011) [19]. CEN cites as examples of biomass: whole or parts of plants, trees, algae, marine organisms, microorganisms, animals, etc.

${ }^{5} \mathrm{OECD}$ estimates that by 2030 the use of biotechnology will account for $35 \%$ of the industrial production of chemical products and of other products that can be manufactured with biotechnology (e.g. bioplastic materials); up to $80 \%$ of pharmaceuticals and diagnostics; and approximately $50 \%$ of agricultural production (OECD, 2009)[8]. 
century.

The decisive factor involves the application of the opportunities brought by the progress of biological sciences and their use to address complex problems.

Bioeconomy seeks, therefore, to separate itself from nature and have more control over it through science. As noted by Carlson (2007, p. 116) [18]: "the work [in biological technologies] will continue because the possibility of improved crop yields, increased meat production, plentiful biofuels, and improved human health through new vaccines and replacement tissues are too scientifically, politically and economically enticing for humans to resist".

\subsection{Bioeconomy and the Bio-Based Economy: Distinction}

The boundary between bioeconomy (BE) and bio-based-economy (BBE) differs between countries, but in general the distinction is made in relation to the production and use of biomass, often with the exclusion of food and feed production.

The distinction is made between bioeconomy, which encompasses the production of biomass, either through primary production (from agriculture, forestry, fishing, aquaculture and industry) or through the collection of waste streams; and the use of biomass for food, energy and material uses.

Bio-based economy is part of the overall bioeconomy and addresses only the use of biomass for materials, energy, chemicals and other bio-based processes, with the explicit exclusion of food (Allen et al., 2015) [20].

Other conceptual definitions that differentiate BE from BBE have emerged, yet they are used without any consensus.

The European Union identifies bio-based economy as one that integrates the full range of natural and renewable biological resources, land and sea resources, biodiversity and biological materials (plant, animal and microbial), including the processing and consumption of these bio-resources (European Commission, 2012) [17]. This definition of the concept focuses on raw materials rather than on the conversion processes and is applied with the same meaning in Germany (BOR, 2011) [21], Finland (Luoma et al., 2011) [9] and Sweden (FORMAS, 2012) [22].

Due to the novel nature of the sector, the understanding and definitions of bioeconomy are continuously being developed as they are confronted with new issues and as a variety of instances approach the bioeconomy sector. This includes producing different products and services by using various biological and technical applications.

\subsection{The Scope of Bioeconomy}

Bioeconomy is an interdisciplinary field that brings together the innovations applied in biological sciences and economic activity and involves different sectors. It comprises (HBR-BR, 2013) [23]:

- Industrial biotechnology: including chemical products, bioplastic materials, enzymes, biosynthesis in yeasts and their application to the development of biofuels, replacement of chemical fertilizers with biological nitrogen fixation and environ- 
mental applications such as bioremediation ${ }^{6}$, bio-sensors and other methods to decrease environmental impacts;

- Primary production: cross-breeding and improvements in plants and animals and veterinary application; and

- Human health: pharmacogenetics, biopharmaceuticals, biofortifiers, dietary, among others.

\section{Others Concepts}

\subsection{Biorefinery}

In a future bioeconomy, sustainable production and valorization of biomass to both food and non-food applications will be the framework of operation ${ }^{7}$. Sustainably produced biomass (crops, algae, residues) has to be used as efficiently as possible-using bio-cascading and biorefining approaches-to meet future demand of food, feed, bioenergy (power, heat and biofuels for transport) and bio-based products (chemicals, materials). The relatively scarce raw material availability requires the development and implementation of high-efficient biomass conversion technologies to maximize valorization and the overall environmental benefits of full biomass supply chains.

To make optimum use of biomass resources, biorefineries that first extract valuable compounds using sustainable technologies and thereafter convert the biomass into other products should be implemented.

A biorefinery refers to a facility that uses a variety of technologies to convert different bio-based feedstocks (trees, energy, crops, waste, ...) into a wide range of products, including food, feed ingredients, chemicals, biomaterials (including fibers) and bioenergy, aiming at maximizing the added value along the three pillars of sustainability (environment, economy and society) (Soetaert, 2009) [24]. It exploits different elements of biomass and turn out more valuable refined products-maybe even producing the energy which powers the process. It usually turns out a mix of low-value, high-volume products into high-value, low-volume products (e.g., cosmetics, drugs, food, supplements, food) (Winther and Klarlund, 2014) [25]. A forest biorefinery, for instance, must use the entire potential of raw materials and by-streams of the forest-based sector for a broad range of products in an efficient way.

The relevant technologies will be those based on white biotechnology and on the principles of green chemistry (Hatti-Kaul et al., 2007) [26].

Biorefineries have been used for many years in the food industry. Large-scale implementation of biorefineries for non-food applications, however, is still lacking. Major reasons for this are that some of the key technologies (fractionation and product separation) being part of integrated biorefinery plants are still not mature enough for commercial market implementation (Bell et al., 2014) [27].

${ }^{6}$ According to the US Environmental Protection Agency, bioremediation is a treatment that uses naturally occurring organisms to break down hazardous substances into less toxic or nontoxic substances. Some examples of bioremediation-related technologies are phytoremediation, bioventing, bioleaching, bioreactor, rhizofiltration, and biostimulation.

${ }^{7}$ Currently, biomass is mainly used for human food, animal feed and the production of fuels. 
In general, first generation biorefineries are based on the direct use of classical forms of agricultural biomass (conversion of sugar-rich biomass into bioethanol by fermentation or conversion of oil-rich biomass into biodiesel by transesterification). Second generation biorefineries are defined as facilities that use lignocellulosic biomass as raw material, one of its biggest advantages being that it reduces the dependence on food crops required by first generation biorefineries. Third generation biorefineries have the advantage of using agricultural, forestry, petrochemical, and urban wastes (Naik et al., 2010) [28].

In recent years, much political focus has been on the development of biofuels. However, the market of bio-based chemicals is also designed to increase significantly (Dornburg et al., 2008) [29].

\subsection{Forestry Industry}

The forest sector is undergoing a significant change due to declining markets of traditional products, which has led to extensive job losses and to rural community upheavals all over the world ${ }^{8}$. Governments are striving to reverse these effects by stimulating new industries focused on the use of sustainable forest biofibre for products such as fuel for energy, chemicals, and polymers (Puddister et al., 2011) [30].

Forest industries, particularly in the Nordic countries, are facing a situation in which new business development and start-ups are crucial due to the mature or even declining state of many parts of the business. The forest industry's reactions to biorefineries and its readiness and resources to operate this change constitute one of the most interesting aspects that arise from some studies. Accordingly, this change is interesting not only from the perspective of the forest industry itself and its potential partners in biorefinery consortia-the change can also be explored from the wider social context as one of the phenomena that embodies society's transition towards a bio-based economy.

In light of these new demands, policy and science experts continue to examine the range of potential forest biomass utilization opportunities in terms of their long-term implications for sustainability and their role in an emerging bioeconomy.

Recently, we have seen a renewed interest in the intensive harvesting of forest biomass as feedstock for bioenergy in Europe and around the world. Globally, the main driving force behind the increased use of biomass for energy is the concern over climate change, with forest biomass being considered a sustainable, renewable energy resource and a sound alternative to fossil fuels. It also increases the diversity of energy sources and, for some countries, improves the security of energy access (Stupak et al., 2007) [31].

The role of forest industry in a forest biorefinery consortium is largely seen to be that of a biomass provider. The scope of change depends on context-specific features, such as biorefinery location and raw material availability.

Operating a commercial-scale biorefinery facility requires both new managerial and

${ }^{8}$ Forest industry includes pulp, paper, paperboard and wood products industries. The latter comprises sawmilling, chipboard, fiberboard and construction products industries. 
operational level skills. Readiness for change needs to be embedded in organizational culture-the key to attaining this is open-minded organizational management (Näyhä et al., 2014) [32].

\subsection{Food Industry}

In a bioeconomy, agricultural crops are not only used to produce food and feed but also to produce chemicals, materials and biofuels.

In agriculture, significant waste volumes of residues are produced, namely, cereal, vegetable, fruit and potatoes' production.

Cereal waste has been more intensely investigated, and it is already known that antioxidants, vitamin E, and plant sterols can be extracted from this resource, which are beneficial for cardiovascular health (Ryan et al., 2007) [33].

Polyphenolic compounds are interesting targets for extraction from waste of several vegetable and fruit production. The identification of other compounds extracted from vegetables and fruit (e.g. oranges and apples) will be of value for further research.

Quercetin, a well-defined molecular product, is an antioxidant identified as potentially extractable from onion by-products, available in large amounts around the world (Murakami et al., 2008) [34]. Today, the use of onion waste is limited to compost, animal feed, or raw material in biogas-production (Ekman and Börjesson, 2011) [35]. The goal is to add value by implementing a sustainable method to first obtain quercetin and then facilitate further use of the remaining waste for biogas production by anaerobic digestion.

\subsection{Microalgae}

Algae are a group of relatively simple organisms, plantlike organisms that live in the waters of the oceans, seas and rivers and are capable of performing photosynthesis. There are tens of thousands of different species of algae with different sizes and varying characteristics, many of which have been investigated. Algae contain lipids (oil), proteins and carbohydrates (sugars).

The use of microalgae in the food and feed market is increasingly relevant as some of their components, such as fatty acids, colorants, and vitamins, have the potential to be competitive with the same components from other sources (Enzing et al., 2014) [36].

Microalgae-based molecules have specific advantages with respect to their synthetic and traditional alternatives that make their use commercially viable for the food sector, despite the higher production costs in comparison to chemical synthesis.

However, the bulk production of carbohydrates and proteins for the food and feed sector is not yet foreseen in the short run, because reducing production costs would require higher production volumes (Enzing et al., 2014) [36].

Microalgae have other functions too. More recently, they have been used in the production of ethanol or biodiesel and research using genetically modified algae for the production of pharmaceuticals is currently underway. They play a crucial role in aquaculture, being incorporated into cosmetics, and are cultivated as a source of highly val- 
uable molecules; e.g. polyunsaturated fatty acid oils that are added to infant formulas and nutritional supplements (Spolaore et al., 2006) [37].

\section{Challenges}

In such a complex context, expanding research in bioscience, either within academia or in the business world, depends on having sophisticated laboratory infra-structures with modern equipment. It is necessary to set up, modernise and expand state-of-the-art research centres, to promote cooperation projects with international reference centres of excellence and to build successful partnerships with the business sector. This requires planning and assertive policies to pursue better alternatives to the use of natural resources and technology and the organization of economic activity without compromising the sustainability of the ecosystem.

A coherent alignment of priorities is therefore necessary, and they should include (HBR-BR, 2013): (i) investments in R\&D, innovation and skills; (ii) policies supporting business development in the areas covered by bioeconomy; (iii) encouragement of entrepreneurship; and (iv) dissemination of innovation culture.

\section{An Overview of Bioeconomy in Europe}

In Europe alone, 16 tons of material are used per person per year, of which 6 tons become waste (Allen et al., 2015) [20]. Thus, the European economy is still losing a significant amount of potential "secondary raw materials" through present waste streams.

Moreover, in 2010 , only $36 \%$ of the total waste generation in the EU (about 2.5 billion tons) was recycled, the remainder being landfilled or burned. It is estimated that around 600 million tons (37.5\%) of what was landfilled could have been recycled or reused (Allen at al., 2015) [20].

As in the case of the definition of bioeconomy itself, the term "waste" is used to signify a variety of different things in different contexts.

The European Waste Framework Directive (EWFD) (Directive 2008/98/EC, 19/11) [38], for instance, defines waste as any substance or object which the holder discards, intends to discard, or is required to discard. This Directive explains when waste ends being waste to become secondary raw material (the so called "end-of-waste criteria"), including certain materials that may be desirable to be used in a developing bioeconomy (e.g. non-hazardous waste for health and the environment, in particular air, water and land) and sets out the definitions and basic concepts regarding waste management.

The Directive includes two new recycling and recovery targets to be achieved by 2020: (i) 50\% preparing for re-use and recycling of certain waste materials from households and other origins similar to households, and (ii) $70 \%$ preparing for re-use, recycling and other recovery of construction and demolition waste.

Reflecting the importance of bioeconomy, the European Commission has adopted a strategy called "Innovating for Sustainable Growth: a Bioeconomy for Europe", which proposes a comprehensive approach to address the ecological, environmental, energy, food supply and natural resource challenges that Europe and the world are facing today 
(European Commission (EC), 2012) [17]. At the same time, it will help address the need for sustainable economic recovery, holding great potential for creating sustainable economic growth and jobs?.

As the world leader in research and innovation in the field of bioeconomy, the EU is well placed to improve the management of its resources and open up new and different markets in food, animal feed, energy and bio-based products.

A strong bioeconomy will help Europe to live within its limits. It will allow the production of more from less, including from waste, while limiting the negative impacts on the environment and reducing the heavy dependency on fossil resources, mitigating climate change and moving Europe towards a post-petroleum society (EC, 2014a) [39].

Under the auspices of the Bioeconomy Strategy, a European Bioeconomy Panel has been set up to support interactions between different policy areas, sectors and stakeholders, in order to get a global overview of the different components and dimensions of the bioeconomy. The Bioeconomy Panel brings together, in one group, people with different perspectives and areas of expertise (business and producers, policy-makers and public administrations, scientists and researchers, and civil society organizations) (EC, 2014b) [40]. Furthermore, the EU Research and Innovation program from 2014 to 2020 (Horizon 2020), also includes research relevant to this sector (EC, 2014c) [41] ${ }^{10}$.

In addition to the EU strategy, several EU Member States have also designed their own national bioeconomy strategies.

\section{Case Studies of Bioeconomy in the Nordic Countries}

Although the concept of bioeconomy has become increasingly popular in the regional, national and international policy discourse in Europe and has been operationalized by the EU for some time, the understanding of the concept varies significantly across Europe. Some Nordic regions have adopted the term bioeconomy, whereas others are now starting to familiarize themselves with the term (Teräs et al., 2014) [13].

\subsection{Bioeconomy in Sweden}

Sweden has chosen a more sustainable base for the economy with the transition towards bioeconomy based on biotechnology and biomass-based production.

Sweden is the world's second largest producer of processed forest products such as paper, pulp and sawn timber. The forest industry generates several by-products, which are used for a number of purposes such as the production of chipboard and plywood or chemicals.

Also, by-products from the forest industry are used in energy generation. Bioenergy

${ }^{9}$ Bioeconomy is already generating growth and employment to millions of people. According to the European Commission, bioeconomy in the EU represents a market estimated to be worth over EUR2 trillion, providing 20 million jobs and accounting for $9 \%$ of the total employment (European Commission, 2012, p. 5)[17].

${ }^{10}$ Horizon 2020 is the biggest EU Research and Innovation program ever, with nearly EUR80 billion of funding available over 7 years (2014 to 2020), in addition to private investment that it will attract. Horizon 2020 is the financial instrument that implements the Innovation Union, a Europe 2020 flagship initiative aimed at securing Europe's global competitiveness. 
already plays an important role in the Swedish energy system due to a combination of the vast biomass resources and active governance to increase the share of renewable energy (e.g. a carbon dioxide tax on fossil fuels). Currently, a large amount of forestry residues is already used for internal energy generation in the forest industry. The total use of logging residues such as tops and branches for energy purposes is more than 7 TWh, but there is a potential to increase this without ecological damage (Swedish Forest Industries Federation, 2009) [42].

Even if it is desirable to use renewable energy from these sources, extraction of valuables at a step preceding energy production is interesting to increase the utilization of the resource (Swedish Forest Industries Federation, 2009) [42].

Sweden has therefore become more motivated to find new processes and added-value products, particularly with a view to the low value of by-products (from agriculture and from forestry industry) and waste streams to increase its product portfolio. It is now well-known that many by-products contain high added-value compounds, such as antioxidants, pigments and other relevant molecules.

Two of the waste products that have been identified, onion waste, from the food industry, and birch bark, from the forestry industry, were more thoroughly studied with a view to maintain their current value as feed materials or as chemical compound materials.

In the case of onion waste, quercitin is obtained chemically. This is a powerful antioxidant which, as studies have shown, can have a positive effect on cancer (Murakami et al., 2008) [34], cardiovascular problems (Cook and Samman, 1996) [43] and neurodegenerative disorders (Ono et al., 2006) [44].

Also chemically obtained from birch bark, the blend of antioxidants and betulin, with its anti-inflammatory and antibacterial properties has also been acknowledged (Paduch et al., 2007) [45]. Betulin is also used as an additive in many cosmetic products. Furthermore, betulinic acid is a powerful agent against a certain type of cancer and HIV (Cichewicz and Kouzi, 2004) [46]. After processing, the remaining waste can be used to produce energy and in some cases it can be recycled as a bio-fertilizer for cultivable land.

\subsection{Bioeconomy in the Lolland Region-Denmark}

The Lolland Region is known internationally as one of Europe's leading regions for its work on climate issues, renewable energies and for developing solutions for the future (Teräs et al., 2014) [13]. This has called for innovative and practical solutions that promise not only alternative energy sources but also new jobs and improved quality of life.

The Lolland region has specialized in the production of energy with a major focus on renewable sources. This sector benefits from its proximity to Copenhagen, where there is a high demand for energy, and increasingly from renewable sources. There is a long tradition of renewable energy in this region.

However, there has been an encouragement to diversify sources and create new 
projects since 2007, because of sustained support to innovation in food and agroindustry, plant production and management assistance in general.

Bioeconomy and resource efficiency are clear priorities for Lolland. The region is very pragmatic regarding bioeconomy: it has plant production, high-tech production and biotechnology, and it should be able to do much more. The ambition is to launch more activities and to change fundamental structures in the long run, inasmuch as bioeconomy is perceived to be about "what can be extracted from plants", "making the most of bio-based value chains", "optimizing and creating symbiosis" and "cascading production" (Teräs et al., 2014) [13].

The Green Center (GC) is a business and research unit that works with agricultural, agribusiness and eco-technology industries in Lolland ${ }^{11}$. The GC generates new products as well as production and management opportunities for its customers and business partners while focusing on sustainability. For instance, the GC focuses on optimizing the use of biomass and works with both naturally occurring and intensively produced biomass from agriculture. The Lolland Region accounts for 18\% of Denmark's total agricultural land and its biomass represents $70 \%$ of the renewable energy production in Denmark, with wind energy being the second most important source and accounting for more than $20 \%$ of total renewable energy (Bassi, 2013) [47].

Biofuel production in Lolland was established in collaboration with public-private partnerships. The biofuels produced include rapeseed oil, biodiesel from algae cultivation and bioethanol from agricultural production.

The GC is testing techniques to cultivate algae on a large scale. Intensive agriculture could produce $\mathrm{CO}_{2}$ and nitrogen, which can be used in the production of algae. The potential uses of algae include purifying water by removing nitrate deposits from intensive farming, and sewage treatment. The Algae Innovation Centre was initiated by the GC in 2010 in partnership with Aalborg University and Roskilde University. The project aims to establish a demonstration and pilot plant for algae cultivation experiments, and to conduct research on how society and businesses can optimally use algae production technologies (Teräs et al., 2014) [13].

Lolland has taken the role of a model region in terms of sustainable economy and green growth, and this has influenced significantly its modes of governance by strengthening co-operation between local communities, private companies, cultural institutions and research institutions (Teräs et al., 2014) [13].

Integrated solutions (including symbiosis and industry/community interactions) represent one important focus area in the development of bioeconomy. This is closely related to projects dealing with side current management and new products. Being early in this field can potentially offer first-mover advantages over other regions and large firms.

\subsection{Nordic Bioeconomy in Figures}

According to Rönnlund et al. (2014) [48], the total turnover of the key bioeconomy

${ }^{11}$ The Green Center (GC) was founded in 1988 on Lolland Island to help farmers to innovate. 
sectors in the Nordic countries is of approximately EUR184 billion (including agriculture, fisheries and aquaculture, forestry, food industry, forest industry and bioenergy and biofuels). In total, this constitutes $10 \%$ of the total Nordic economy. According to the same report, the current volume of bioeconomy accounts for $9 \%$ of the economy in Denmark, 12\% in Finland, 18\% in Iceland, 6\% in Norway and 10\% in Sweden.

Still, growth areas are found in a wide range of fields such as bio-based chemicals, biorefineries and industrial symbiosis. Also, it has been established that in the Nordic region, the largest innovation and growth potential in the area of bioeconomy lies in its cross-cutting nature (Rönnlund et al., 2014) [48]. Crossing horizontal sectors is identified as a central factor in the development of bioeconomy in the Nordic region.

\section{Conclusions}

Knowledge and technological innovation, recognized as symbols of the emancipation of human beings cannot continue to be used as social exclusion mechanisms at the service of those (few), who, for their own advantage, invest in economic growth at any price at the cost of natural capital depletion and of the deterioration of natural values which are vital and upon which the vast majority of other resources depend.

Modern civilisation - scientific and technical-has been based on a particular definition of nature and of man-nature relationship which has been increasingly questioned over the last few decades. Nature was perceived by seventeenth-century philosophers (such as Descartes) as a realm over which Man ruled as lord and master, free to do whatever he pleased. There were no boundaries for human science and industry. A new attitude towards nature that is neither dominating nor worshipful, as if the purpose was to restore the ancient naturalist gods (Jesus, 1997) [49], must be adopted.

Sustainable systems of production and consumption are inevitable to respond to societal challenges, such as natural resource scarcity and a wiser management of natural resources, climate change, environmental pollution, improvement of food security in view of the expected increase in world population and employment generation. Moreover, the current global crisis has accelerated the need to rethink today's development models.

The standards for future models should rest upon the inclusion of environmental concerns as a basic component of economic and social policies, rather than merely looking at the protection of nature as an "added value".

An economy founded on biomass instead of fossil fuels represents a significant shift in socio-economic, agricultural, energy and technical systems. This type of economy can meet many of the requirements for sustainability from environmental, social and economic perspectives, if it is designed and implemented in an intelligent way.

In this context, it can reasonably be assumed that bioeconomy as an economic, social and political project will guide the future and will be an opportunity for the decoupling of industrial growth and environmental degradation by using production methods based on biotechnology at an industrial scale.

The challenge posed by a limited offer of resources and the balance between sustain- 
ability and economic aspirations turns bioeconomy into a promising industry, even if it is still emerging and therefore needs policies that stimulate its development.

Furthermore, the creation of new non-food markets for agriculture (such as bioenergy) in synergy with existing food markets, and in combination with alternative income sources for farmers, can give rural areas a major boost (EuropaBio, 2011) [50].

This paper tried to show that bioeconomy is far more than a mere evolution of knowledge-based economy, although it is part of the latter, towards a more intelligent, sustainable and inclusive economy. The challenge faced by our millennium lies in achieving the balance between the technical means of humanity and how wisely we will use them.

\section{References}

[1] Murray, S.J., Foster, P.N. and Prentice, I.C. (2012) Future Global Water Resources with Respect to Climate Change and Water Withdrawals as Estimated by a Dynamic Global Vegetation Model. Journal of Hydrology, 448-449, 14-29.

http://dx.doi.org/10.1016/j.jhydrol.2012.02.044

[2] Daly, H.E. (2015) Economics in a Full World. Scientific American, 100-107.

[3] UN (2010) Report Global Biodiversity Outlook (GBO-3) 2010.

[4] IEA (2013) World Energy Outlook 2013. International Energy Agency, Paris.

[5] FAO (2012) World Agriculture towards 2030/2050: The 2012 Revision. ESA Working Paper 12-03, United Nations Food and Agriculture Organization, Rome.

[6] Rulli, M.C., Saviori, A. and D’Odorico, P. (2013) Global Land and Water Grabbing. Proceedings of the National Academy of Sciences, 110, 892-897.

http://dx.doi.org/10.1073/pnas.1213163110

[7] IPCC (2013) Climate Change 2013: The Physical Science Basis. Contribution of Working Group I to the Fifth Assessment Report of the Intergovernmental Panel on Climate. Cambridge University Press, Cambridge.

[8] OECD (2009) The Bioeconomy to 2030: Designing a Policy Agenda, Main Findings and Policy Conclusions. OECD, Paris.

[9] Luoma, P., Vanhanen, J. and Tommila, P. (2011) Distributed Bio-Based Economy-Driving Sustainable Growth. Finnish Innovation Fund (SITRA), Helsinki.

[10] DESA/UN (2015) World Urbanization Prospects: The 2014 Revision. Department of Economic and Social Affairs, Population Division, United Nations, New York.

[11] UN (2013) World Population Prospects: The 2012 Revision. UN Department of Economic and Social Affairs, New York.

[12] Kharas, H. (2010) The Emerging Middle Class in Developing Countries. OECD Development Centre, Working Paper No 285.

[13] Teräs, J., Lindberg, G., Johnsen, I.H., Perjo, L. and Giacometti, A. (2014) Bioeconomy in the Nordic Region: Regional Case Studies. Nordregio (Nordic Center for Spacial Development) Working Paper 4.

[14] Kleinschmit, D., Lindstad, B.H., Thorsen, B.J., Toppinen, A., Roos, A. and Baardsen, S. (2014) Shades of Green: A Social Scientific View on Bioeconomy in the Forest Sector. Scandinavian Journal of Forest Research, 29, 402-410. http://dx.doi.org/10.1080/02827581.2014.921722

[15] DG Research (2006) FP7 Theme 2: Food, Agriculture, Fisheries and Biotechnology. 2007 
Work Programme.

[16] EPSO (2011) The European Bioeconomy in 2030: Delivering Sustainable Growth by Addressing the Grand Societal Challenges. European Plant Science Organisation.

[17] European Commission (2012) Innovating for Sustainable Growth: A Bioeconomy for Europe. COM (2012) 60.

http://ec.europa.eu/research/bioeconomy/pdf/official-strategy_en.pdf

[18] Carlson, R. (2007) Laying the Foundations for a Bio-Economy. Systems and Synthetic Biology, 1, 109-117. http://dx.doi.org/10.1007/s11693-007-9010-Z

[19] CEN (2011) Biobased Products-Overview of Standards (CEN/TR 16208:2011). European Committee for Standardisation (CEN).

[20] Allen, B., Nanni S., Schweitzer, J.-P., Baldock, D., Watkins, E., Withana, S. and Bowyer, C. (2015) International Review of Bio-Economy Strategies with a Focus on Waste Resources. Report Prepared for the UK Government Department for Business, Innovation and Skills. Institute for European Environmental Policy, London.

[21] BOR (2011) Bio-Economy Innovation-Research and Technological Development to Ensure Food Security, the Sustainable Use of Resources and Competitiveness. Bioeconomy Council Report 2010. The Bio-Economy Research and Technology Council (BOR), Berlin.

[22] FORMAS (2012) Swedish Research and Innovation. Strategy for Bio-Based Economy. Report. Stockholm: Swedish Research Council for Environment, Agricultural Sciences and Spatial Planning (FORMAS).

[23] HBR-BR (2013) Bioeconomia-Uma Agenda para o Brasil. Harvard Business Review, Brasil.

[24] Soetaert, W. (2009) Defining Biorefineries and Different Concepts. BioreFuture.

[25] Winther, T. and Klarlund, H. (2014) A Bioeconomy for the Baltic Sea Region-Impact, Engaging the Private Sector and Financing Cooperation, Workshop Paper, Berlin, 18-19 September2014.

http://bsrbioeconomy.net/resources/BSR_Bioeconomy_Berlin_workshop_paper_September 2014.pdf

[26] Hatti-Kaul, R., Törnvall, U., Gustafsson, L. and Börjesson, P. (2007) Industrial Biotechnology for the Production of Bio-Based Chemicals-A Cradle-to-Grave Perspective. Trends in Biotechnology, 25, 119-124. http://dx.doi.org/10.1016/j.tibtech.2007.01.001

[27] Bell, G., Schuck, S., Jungmeier, G., Wellisch, M., Felby, C., Jørgensen, H. and Spaeth, J. (2014) IEA Bioenergy Task42 Biorefining. Wageningen: IEA Bioenergy.

[28] Naik, S.N., Goud, V.V., Rout, P.K. and Dalai, A.K. (2010) Production of First and Second Generation Biofuels: A Comprehensive Review. Renewable and Sustainable Energy Reviews, 14, 578-597. http://dx.doi.org/10.1016/j.rser.2009.10.003

[29] Dornburg, V., Hermann, B.G. and Patel, M.K. (2008) Scenario Projections for Future Market Potentials of Biobased Bulk Chemicals. Environmental Science \& Technology, 42, 2261-2267. http://dx.doi.org/10.1021/es0709167

[30] Puddister, D., Dominy, S., Baker, J., Fleming, R. and Wetzel, S. (2011) Opportunities and Challenges for Ontario's Forest Bioeconomy. The Forestry Chronicle, 87, 468-477. http://dx.doi.org/10.5558/tfc2011-045

[31] Stupak, I., Asikainen, A., Jonsell, M., Ravn, H. and Tamminen, P. (2007) Sustainable Utilization of Forest Biomass for Energy-Possibilities and Problems: Policy, Legislation, Certification, and Recommendations and Guidelines in the Nordic, Baltic, and Other European Countries. Biomass and Bioenergy, 31, 666-684.

http://dx.doi.org/10.1016/j.biombioe.2007.06.012 
[32] Näyhä, A. and Pesonen, H. (2014) Strategic Change in the Forest Industry towards the Biorefining Business. Technological Forecasting and Social Change, 81, 259-271. http://dx.doi.org/10.1016/j.techfore.2013.04.014

[33] Ryan, E., Galvin, K., O’Connor, T.P., Maguire, A.R. and O’Brien, N.M. (2007) Phytosterol, Squalene, Tocopherol Content and Fatty Acid Profile of Selected Seeds, Grains, and Legumes. Plant Foods Hum. Nutr., 62, 85-91. http://dx.doi.org/10.1007/s11130-007-0046-8

[34] Murakami, A., Ashida, H. and Terao, J. (2008) Multitargeted Cancer Prevention by Quercetin. Cancer Lett., 269, 315-325. http://dx.doi.org/10.1016/j.canlet.2008.03.046

[35] Ekman, A. and Börjesson, P. (2011) Environmental Assessment of Propionic Acid Producedin an Agricultural Biomass-Based Biorefinery System. Journal of Cleaner Production, 19, 1257-1265. http://dx.doi.org/10.1016/j.jclepro.2011.03.008

[36] Enzing, C., Ploeg, M., Barbosa, M. and Sijtsma, L. (2014) Microalgae-Based Products for the Food and Feed Sector: An Outlook for Europe. Joint Research Centre Scientific and Policy Reports.

[37] Spolaore, P., Joannis-Cassan, C., Duran, E. and Isambert, A. (2006) Commercial Applications of Microalgae. Journal of Bioscience and Bioengineering, 101, 201-211.

[38] Directive 2008/98/CE of the European Parliament and of the Council of 19 November 2008. European Waste Framework Directive (EWFD).

[39] European Commission (2014a) Where Next for the European Bioeconomy? http://ec.europa.eu/research/bioeconomy/pdf/where-next-for-european-bioeconomy-repor t-0809102014_en.pdf

[40] European Commission (2014b) Bioeconomy Panel. http://ec.europa.eu/research/bioeconomy/policy/panel_en.htm

[41] European Commission (2014c) Horizon 2020. Food Security, Sustainable Agriculture and Forestry, Marine, Maritime and Inland Water Research and the Bioeconomy. https://ec.europa.eu/programmes/horizon2020/en/h2020-section/food-security-sustainable -agriculture-and-forestry-marine-maritime-and-inland-water

[42] Swedish Forest Industries Federation (2009) The Forest Industry in Facts and Figures. Stockholm.

[43] Cook, N.C. and Samman, S. (1996) Flavonoids-Chemistry, Metabolism, Cardioprotective Effects, and Dietary Sources. Journal of Nutritional Biochemistry, 7, 66-76. http://dx.doi.org/10.1016/0955-2863(95)00168-9

[44] Ono, K., Hamaguchi, T., Naiki, H. and Yamada, M. (2006) Anti-Amyloidogenic Effects of Antioxidants: Implications for the Prevention and Therapeutics of Alzheimer's Disease. Biochimicaet Biophysica Acta (BBA) - Molecular Basis of Disease, 1762, 575-586. http://dx.doi.org/10.1016/j.bbadis.2006.03.002

[45] Paduch, R., Kandefer-Szerszen, M., Trytek, M. and Fiedurek, J. (2007) Terpenes: Substances Useful in Human Healthcare. Arch. Immunol. Ther. Exp, 55, 315-327. http://dx.doi.org/10.1007/s00005-007-0039-1

[46] Cichewicz, R.H. and Kouzi, S.A. (2004) Chemistry, Biological Activity, and Chemotherapeutic Potential of Betulinic Acid for the Prevention and Treatment of Cancer and HIV Infection. Med. Res. Rev., 24, 90-114. http://dx.doi.org/10.1002/med.10053

[47] Bassi, A.M. (2013) Analyzing the Impact of a National Green Economy Strategy on Small Communities: The Case of Lolland Municipality. Energy Series Working Paper 7, KnowlEdgeSrl.

[48] Rönnlund, I., Pursula, T., Bröckl, M., Hakala, L., Luoma, P., Aho, M. and Pathan A. (2014) Creating Value from Bioresources-Innovation in Nordic Bioeconomy. Nordic Innovation 
Report 2014:01, Nordic Innovation, Oslo.

[49] Jesus, L.M. (1997) A questão de Deus na Filosofia de Descartes. Coleção Filosofia, Porto Alegre.

[50] European Association for Bioindustries (EuropaBio) (2011) Building a Bio-Based Economy for Europe in 2020. European Association for Bioindustries, Brussels, 2011.

Submit or recommend next manuscript to SCIRP and we will provide best service for you:

Accepting pre-submission inquiries through Email, Facebook, LinkedIn, Twitter, etc. A wide selection of journals (inclusive of 9 subjects, more than 200 journals)

Providing 24-hour high-quality service

User-friendly online submission system

Fair and swift peer-review system

Efficient typesetting and proofreading procedure

Display of the result of downloads and visits, as well as the number of cited articles Maximum dissemination of your research work

Submit your manuscript at: http://papersubmission.scirp.org/

Or contact jss@scirp.org 